\title{
REVIEW
}

\section{Diversified Approaches to Evaluate Wide Genetic Resources of Cowpea for Enhancing New Variety Development for West Africa and Its Social Implementation by Cowpea Research Program of IITA}

\author{
Haruki ISHIKAWA $^{1 *}$ and Ryo MATSUMOTO ${ }^{1}$ \\ ${ }^{1}$ International Institute of Tropical Agriculture (IITA), Ibadan, Oyo State, Nigeria
}

\begin{abstract}
Cowpea is a staple food crop and a primary source of protein for millions of people in developing countries. Although the crop is primarily cultivated for its mature grains, immature green pods and young green leaves can be consumed as a vegetable. The International Institute of Tropical Agriculture (IITA) was established in 1967; the organisation's extensive research has developed many improved varieties of most staple food crops to benefit people across Africa. For example, more than 100 IITAbred materials and numerous germplasm lines of cowpea from the Genetic Resource Center (GRC) of IITA which is a mandate crop have been distributed across sub-Saharan Africa. Currently, IITA GRC houses one of the largest global cowpea collections of over 17,000 accessions from 89 countries. Here, we review the diverse approaches undertaken in cowpea research to evaluate the wide genetic resources of IITA for the development of new varieties and their successful dissemination. Notably, Japanese scientists have made constructive contributions to the progress in cowpea research at IITA over the past 50 years. Finally, in terms of research for development, collaborative measures among various national and international stakeholders for the appropriate delivery and social implementation of research achievements in the future are discussed.
\end{abstract}

Discipline: Crop science

Additional key words: crop phenotyping, development of evaluation methods/techniques, partnership for delivery, research for development

\section{Transforming Africa's agriculture and nourishing rural development}

On 27 July 1967, the International Institute of Tropical Agriculture (IITA) was established as an autonomous, non-profit corporation by a decree of the Federal Military Government of Nigeria to contribute towards global food security. IITA was created with expectation to implement an African version of the Green Revolution that transformed Asia through increased agricultural production in the 1960s. It became the first major African link in an integrated network of international agricultural research centers across the developing world (IITA 2017b). IITA focuses on three strategic objectives: (1) increasing food security and availability, (2) increasing the profitability of food crops and other agricultural products, and (3) sustainable management of natural resources. Its research is organised around several core themes: improving crop varieties, enhancing nutrition, managing natural resources, and increasing livelihoods. The institute also works on special initiatives, including youth engagement in agribusiness, commercialisation of technologies in a business incubation platform, women empowerment, development of seed systems, protection and conservation of biodiversity, and big data and open access. Presently, IITA has become the largest international agriculture research center in tropical Africa (budget size, number of researcher), contributing to food and nutrition security in the region.

The impact of IITA on the progress of smallholder farmers is evident in their adoption of improved varieties of many staple food crops in the continent. This includes

*Corresponding author: h.ishikawa@cgiar.org

Received 1 February 2021; accepted 9 June 2021. 
the adoption of almost 400 varieties of cassava with increased yields and better resistance to pests, disease, and environmental stresses; more than 100 IITA-bred materials and several hundreds of cowpea accessions; 327 maize varieties ( $70 \%$ of which have IITA germplasm); 78 improved yam varieties; drought-tolerant maize in 13 countries in eastern, western, and southern Africa with projected economic gains of US\$ 907 million; introduction of cowpea and soybean as a food and cash crop in West Africa; and awareness of nutritional benefits of biofortified yellow cassava (IITA 2017b, 2018). IITA has made great contributions to national food security and capacity development of African researchers and scientists in agriculture as well as support to other agriculture research systems in the continent. The institution has trained over 140,000 individuals from 68 countries, and more than 40,000 of them are women.

From its inception, the institute has had a major focus on plant breeding. It is noteworthy that this mainly included improvements in crop quality and yield, and distributes planting materials to other institutes. However, variety development was not done in isolation; it was an integral part of farming systems along with improvements in soil fertility, farm management, natural resource management, control of insects and diseases, evaluation of various genetic resources and screening methodology, understanding farmer/consumer preferences in the target areas, and social implementation/dissemination of new varieties.

During its half-century run as of 2017, the personnel of IITA included 25 Japanese researchers; seven Japanese board members contributed to the administration and decision-making at IITA (Table 1). In addition, the Japanese government has supported IITA from its early stages as one of the most important donors, and numerous collaborative projects were conducted with Japanese institutes/universities. The first mention of a Japanese scientist in IITA was Dr. Seizo Matsushima in 1976, and Japan was listed in 1978 as a research support/donor. In particular, most Japanese scientists and their research budgets are supported by the Ministry of Agriculture, Forestry and Fisheries of Japan (MAFF Japan), the Ministry of Foreign Affairs of Japan (MoFA Japan), and the official development assistance (ODA) project. This article reviews diverse approaches that were undertaken to evaluate the wide genetic resources of IITA for the development of new varieties of cowpea and their social implementation. In addition, the contributions of Japanese researchers are presented in this article.

\section{Introduction of cowpea and its silent food revolution from Nigeria}

The cowpea is both an "ancient" as well as a "contemporary" staple crop and food. Early illustrations of the plants from AD 512 revealed that farmers had been growing early-maturing strains of the crop with a "determinate" growth habit, perhaps as a strategy to obtain a grain crop and avoid impending terminal drought; cowpea is indeed considered a strategic crop species to address the complex challenges of hunger, malnutrition, climate change, and increasing food prices that would confront the global community (Widders 2012). Cowpea (Vigna unguiculata [L.] Walp.) is an herbaceous annual grain legume crop that is mostly grown in the dry, tropic agro-ecologies of Latin America, Africa, Southern Europe, the USA, and South Asia. Cowpea is an important food security crop in developing countries and cultivated mostly for its edible mature grains to feed millions of people (Tarawali et al. 1997). Nutritionally, cowpea grains contain, on average, $23-32 \%$ protein and $50-60 \%$ carbohydrate (Cruz et al. 2014), on a dry basis. It is a nutritious and inexpensive source of protein for both rural poor and urban consumers (Inaizumi et al. 1999). Green pods with immature seeds can also be consumed as a vegetable (Ehlers \& Hall 1997, Mortimore et al. 1997). In West Africa, eating the green pods is crucial for escaping the "hungry period" of August and September (Hall 2012; Badiane et al. 2014). Additionally, cowpea fodder is a valuable source of feed for livestock (Singh et al. 2003), making it very attractive to small-scale farmers (Kamara et al. 2012). As a leguminous crop, cowpea improves soil fertility through its ability to fix atmospheric nitrogen (Sanginga et al. 2000) and is tolerant to low soil fertility, including low phosphate levels (Suzuki et al. 2018). Collectively, these characteristics have made cowpea a vital component of cropping systems for the dry savannahs of sub-Saharan Africa (SSA) (Table 2; Carsky et al. 2001).

The annual global production of cowpea is approximately 8.92 million metric tons (FAOSTAT 2021), and the bulk of production and consumption is in SSA, particularly in West and Central Africa (Table 3). One other major cowpea-producing country is Brazil, with an annual production of more than 491,000 tons (Singh et al. 2002). Nigeria produces the highest quantity of cowpea grains annually and consumes more than 3.0 million metric tons (Boukar et al. 2018). According to Ortiz (1998), Nigerian cowpea production increased by 441\% from 1971 to 1996. As a reference, average production of wheat and rice was increased by $338 \%$ and $123 \%$, respectively, during the "Green Revolution" in Asia between 1961 and 1991. This example shows how IITA (based in Ibadan, Nigeria) has 
Table 1. List of Japanese board members and researchers in IITA during 1967-2020

\begin{tabular}{|c|c|c|c|}
\hline Name & Year (in) & Year (out) & Remarks \\
\hline Hidetsugu Ishikura & 1981 & 1986 & Member of IITA Board of Trusty \\
\hline Kunio Toriyama & 1986 & 1989 & Member of IITA Board of Trusty \\
\hline Keiko Nakamura & 1989 & 1994 & Member of IITA Board of Trusty \\
\hline Kyoko Saio & 1994 & 2001 & Member of IITA Board of Trusty \\
\hline Masaru Iwanaga & 2001 & 2002 & Member of IITA Board of Trusty \\
\hline Akira Iriyama & 2003 & 2005 & Member of IITA Board of Trusty \\
\hline Shuichi Asanuma & 2018 & - & Member of IITA Board of Trusty \\
\hline Yoshitaka Tanaka & 1977 & 1980 & Rice pathologist \\
\hline Shuichi Asanuma & 1979 & 1983 & Soil microbiologist \\
\hline Jyunichi Yamaguchi & 1980 & 1982 & Rice physiologist \\
\hline Takashi Kosaki & 1982 & 1985 & Soil scientist \\
\hline Kikuo Wasano & 1983 & 1984 & Rice breeder \\
\hline Minoru Yamauchi & 1985 & 1986 & Rice Physiologist \\
\hline Toshiyuki Wakatsuki & 1986 & 1988 & Soil scientist \\
\hline Hiroo Kanno & 1988 & 1990 & Yam entomologist \\
\hline Osamu Nakayama & 1989 & 1991 & Food technologist \\
\hline Ryohei Terauchi & 1990 & 1991 & Yam Geneticist \\
\hline Iwao Watanabe & 1990 & 1992 & Plant physiologist \\
\hline Tomio Terao & 1992 & 1995 & Rice physiologist \\
\hline Yukihiro Hayashi & 1994 & 1995 & Agroecologist, system agronomist \\
\hline Hiroki Inaizumi & 1996 & 1998 & Agricultural economist \\
\hline Takehiko Matsui & 1998 & 2001 & Physiologist \\
\hline Fusako Ishida & 1998 & 2001 & Rice science and rural development specialist \\
\hline Hironobu Shiwachi & 2000 & 2004 & Yam physiologist \\
\hline Taro Adati & 2001 & 2003 & Entomologist \\
\hline Hidehiko Kikuno & 2003 & 2012 & Yam physiologist \\
\hline \multirow[t]{2}{*}{ Satoru Muranaka } & 2004 & 2011 & Crop scienstist \\
\hline & 2012 & - & JIRCAS visiting scinentist \\
\hline Haruki Ishikawa & 2010 & - & Plant physiologist \\
\hline Yukiko Kashihara & 2012 & 2015 & Tissue culture specialist \\
\hline Kanako Suzuki & 2013 & 2017 & Soil scientist \\
\hline Ryo Matsumoto & 2011 & - & Yam agronomist \\
\hline Kohtaro Iseki & 2016 & - & JIRCAS visiting scientist \\
\hline
\end{tabular}

been fulfilling its mandate for increasing the production of neglected legume crops such as cowpea (Ortiz 1998). This successful increase in cowpea production involved several methods, such as strengthening and developing partnerships with the National Agricultural Research Institute (NARI), improvement of food policy, and multidisciplinary approaches for sustainable production. One of the key elements is the development of new cowpea cultivars, which combine stable yields with resistance to multiple diseases and pests (including parasitic weeds), optimal photosensitivity, early maturity, erect or determinate growth, and drought tolerance (Latunde Dada 1987).
Conversely, many other abiotic and biotic factors are responsible for low yields, and constitute major constraints for cowpea production. Although cowpea production in Nigeria has improved appreciably over the past 50 years, it is still insufficient to meet the market and consumer demands. With the global population predicted to reach approximately 9 billion by 2050 , many countries, especially SSA countries, would face increased food insecurity (Alexandratos 1999). 
Table 2. Most important food legumes in Africa ${ }^{1}$

\begin{tabular}{llrrr}
\hline \hline Crop & Scientific name & Area harvested (ha) & Production (tons) & Yield (kg/ha) \\
\hline Cowpeas, dry & Vigna unguiculata & $14,205,204$ & $8,616,443$ & 607 \\
Beans, dry & other beans & $7,893,915$ & $7,052,612$ & 893 \\
Soybeans & Glycine max & $2,470,555$ & $3,097,318$ & 1,254 \\
Broad beans, horse beans, dry & Vicia faba & 763,139 & $1,468,881$ & 1,925 \\
Pigeon peas & Cajanus cajan & 529,522 & 666,875 & 1,259 \\
Peas, dry & Pisum sativum & 471,025 & 555,617 & 1,180 \\
Chick peas & Cicer arietinum & 426,203 & 693,369 & 1,627 \\
Bambara beans & Vigna subterranea & 370,953 & 228,920 & 617 \\
Peas, green & Pisum sativum & 120,903 & 651,481 & 5,389 \\
Lupins & Lupinus albus & 109,489 & 75,381 & 689 \\
\hline
\end{tabular}

${ }^{1}$ FAOSTAT, 2021 accessed 11 May 2021

Table 3. Top 20 cowpea producing countries in the world (2019) ${ }^{1}$

\begin{tabular}{|c|c|c|c|}
\hline Country & Production (tons) & Area harvested (ha) & Yield (kg/ha) \\
\hline Nigeria & $3,576,361$ & $4,303,005$ & 831 \\
\hline Niger & $2,386,735$ & $5,725,433$ & 417 \\
\hline Burkina Faso & 652,454 & $1,354,100$ & 482 \\
\hline Brazil $^{2}$ & 491,000 & - & - \\
\hline Ethiopia & 374,332 & 220,037 & 1,701 \\
\hline Mali & 246,870 & 298,120 & 828 \\
\hline Ghana & 215,436 & 454,274 & 474 \\
\hline Cameroon & 215,016 & 244,058 & 881 \\
\hline Kenya & 202,735 & 149,102 & 1,360 \\
\hline Sudan & 184,137 & 290,677 & 634 \\
\hline Senegal & 161,000 & 339,780 & 474 \\
\hline United Republic of Tanzania & 127,884 & 112,657 & 1,135 \\
\hline Myanmar & 108,021 & 122,637 & 881 \\
\hline Mozambique & 90,461 & 331,424 & 273 \\
\hline Democratic Republic of the Congo & 76,292 & 175,418 & 435 \\
\hline Malawi & 66,190 & 26,062 & 2,540 \\
\hline Yemen & 41,656 & 97,825 & 426 \\
\hline Haiti & 31,069 & 34,122 & 911 \\
\hline Madagascar & 30,741 & 42,145 & 729 \\
\hline United States of America & 21,539 & 15,794 & 1,364 \\
\hline Serbia & 15,862 & 4,712 & 3,366 \\
\hline
\end{tabular}

${ }^{1}$ FAOSTAT, 2021 accessed 11 May 2021

${ }^{2}$ Singh et al. (2002)

\section{Extensive genetic resources for cowpea and geographical domain of IITA}

By 1974, IITA was working on a relatively wide range of crops, including maize, cowpea, soybean, banana/ plantain, cassava, yam, sweet potato, rice, cocoyam, lima bean, pigeon pea, winged bean, African yam bean, and velvet bean. A key development was the opening of the Genetic Resources Unit (now Genetic Resources Center,
GRC) with a mission to collect, conserve, and characterise the genomes of African grain legumes, rice, and root and tuber crops. It was agreed that the geographical domain of IITA would include all humid and sub-humid tropical zones. The focus on mandate crops (maize, cowpea, soybean, cassava, yam, and banana/plantain) was developed in the early 1990s and included the transfer of work on sweet potato to the International Potato Center (CIP) and the regional rice mandate to WARDA (now 
Africa Rice Center).

IITA houses one of the largest global cowpea collections with more than 17,000 accessions from 89 countries (IITA Cowpea database: http://my.iita.org/ accession2/). The collection started with 2,040 accessions led by the Grain Legume Improvement Program (GLIP) in 1970-1971 (IITA 1972). In 1974, data on germplasm collection and evaluation were summarised as "Cowpea Germplasm catalog", published with 3,800 accessions. VITA-1 (TVu201-1D), VITA-2S (VMS-2×TVu4552), and VITA-3 (TVu-1190 E-1) were registered in Nigeria in 1974 (IITA 1975). Subsequently, based on geographical, agronomical, and botanical descriptors, a core collection of 2,062 accessions was established (Mahalakshmi et al 2007). A reference set, also called the mini core, was composed with 370 accessions representing the entirety of the genetic diversity of the core. The mini core is a critical resource for scientists to study new adaptive traits, conduct comparative genomics studies, and discover new favourable alleles and lines for pre-breeding activities (Boukar et al. 2018). In addition, the first cowpea Multiparent Advanced Generation InterCross (MAGIC) population was developed as an important genomic community resource for trait discovery and breeding by scientists at the University of California, Riverside, USA (Huynh et al. 2018). During this period, researchers identified the various constraints for cowpea production in Africa and engaged consumers/farmers to accept new varieties of cowpea other than their preferred ones (e.g. IITA 1974, 1975, 1977, 1982).

\section{Droughty summers: A major constraint to cowpea production}

Rain-fed crops growing in the semiarid tropical zone of Africa are subject to extremely dry and hot conditions. Since 1968, droughts have occurred very often in the Sahelian zone, resulting in very short growing seasons. Although cowpea is one of the most drought-tolerant field crops, the very frequent droughts in these regions lead to critical yield loss and consequently, an increased risk of food shortage. Therefore, the importance of earlyand extra-early maturing cowpea was pointed out to escape a droughty season, and programs were initiated to develop extra-early maturing varieties. A number of early-maturing germplasm lines and individual plants from various segregating populations were then selected by IITA (IITA 1982).

IITA and the Japan International Research Center for Agricultural Sciences (JIRCAS) team first evaluated the drought tolerance of 900 cowpea lines at the seedling stage during the 1990/91 dry season (IITA 1995). Watanabe
(IITA Kano station 1990-1992) developed the evaluation methods for drought tolerance by both the identification of tolerance genes and the selection of segregating materials after crossing (Watanabe 1998). Using these methods, 21 germplasm lines were found to be highly drought-tolerant, out of 900 lines. Watanabe \& Terao (IITA Kano station 1992-1995) found high grain yielding lines from the highly drought-tolerant lines (Watanabe \& Terao 1998). Matsui (IITA Kano station 1998-2001) and Singh developed simple screening techniques that use visual observations of young plants subjected to drought and recovery and studied the resistance mechanisms to vegetative-stage drought in cowpea as compared with the other species (Singh \& Matsui 2002). Approximately 190 breeding lines were screened using the box method, and most of them (148 lines) exhibited substantial survival of vegetative-stage drought.

The initial concept of early-maturing cowpea (60-day cowpea) was born in 1979 at the Agricultural Research Institute (ARI) in Tanzania, by IITA/USAID/TANZANIA project (Singh 2014). The region has bimodal rainfall with a long rainy season and a short rainy season. It was thought that an extra-early (60-70 days) maturing grain legume crop would be ideal for the short rainy season in terms of food security and would work well in cereallegume rotation with maize. IITA cowpea breeding team planted all the available germplasm, and selected the lines maturing between 60 and 65 days (Singh 2014). During 1979-1981, selected cowpeas were tested for grain yield (target yield of over 1.5-2 t/ha), resistance to major diseases, wide adaptability, and diverse seed types (IITA 1982). From 1982 onwards, a large number of 60day cowpea varieties were evaluated and released by IITA (IITA 2018, Abaidoo et al. 2017).

Based on these studies and other breeding activities, IITA holds various drought-tolerant/extra-early maturing cowpeas (Supplemental Table S1), which are transported or disseminated to many sub-Saharan countries to escape a droughty summer.

\section{The enemies below: Another major constraint for cowpea production in Africa}

Farmers are not likely to adopt a new cultivar simply because it has an improved adaptation to drought (Hall 2004). They prefer insect and/or disease resistance as well. Cowpea production is typically affected by a number of insect pest species. Troublingly, the crop has many natural enemies in each growth stage. Cowpea seedlings can be attacked and killed by aphids (Aphis craccivora). The flower bud thrips (Megalurothirips sjostedti) are other major insect pests of cowpea that inhibit anthesis and 
pod formation. The legume pod borer, Maruca vitrata, the most cosmopolitan of cowpea pests, is capable of causing extensive grain yield reduction $(20 \%-80 \%)$ if not controlled (Singh et al. 1990, Adati et al. 2012). A number of pod-sucking bugs (Clavigralla tomentosicollis, Riptortus dentipes, and Nezara viridula) attack the pods and suck sap from the seeds while they still develop within the pods (Boukar et al. 2018). Such seeds become seriously reduced in size and malformed, making them unviable and unattractive to farmers and consumers. In addition, when cowpea seeds are placed in storage, the larvae of weevils (Piezotrachelus varius), and bruchids (Callosobruchus maculatus), which often accompany seeds from the field, cause extensive damage by feeding inside and boring holes through which the adults emerge.

Cowpea is also affected by several fungal, bacterial, and viral diseases, causing extensive yield reductions (Boukar et al. 2018). The major characteristic disease of cowpea is bacterial blight caused by Xanthomonas axonopodis pv. phaseoli. Among fungal diseases are preemergence and postemergence damping-off caused by Pythium ultimum, Fusarium wilt caused by Fusarium oxysporium, Macrophominablight caused by Macrophomina phaseolina, web blight, root rot caused by Thanatephorus cucumeris (Rhizoctonia solani), stem rot caused by Phytophthora vignae, scab caused by Sphacelama sp., and cercospora leaf spot caused by Pseudocercospora cruenta and Cercospora apii (Singh 2014, Boukar et al. 2018). Cowpea farmers in sub-Saharan Africa are looking forward to the development and deployment of improved varieties characterised by resistance to these various biotic constraints.

Varieties that are resistant to some insect pests have been developed after evaluating hundreds of germplasm accessions from IITA GRC since 1974 (Supplemental Table S2). However, their resistance levels may not be sufficient for practical use (Adati et al. 2008, Singh et al. 2002). Field screening data for varietal resistance are often unreliable because it is not easy to exclude the effects of climate change, crop phenology, and the timing of insect infestation, which differs among sites and years. These studies have highlighted the global trend of integrated pest management (IPM), which is intended to reduce the harmful impact of synthetic pesticides on the environment (Adati et al. 2008). Components of IPM strategies for cowpea in the West Africa savannahs include the use of resistant cowpea varieties, cropping systems, botanical insecticides, biological control, and pest monitoring. Regarding other approaches for IPM, Adati (IITA Kano station 2001-2003) and Tatsuki identified the female sex pheromone of Maruca (Adati \& Tatsuki 1999), based on the results of which Downham et al. developed sex pheromone traps for monitoring Maruca (Downham et al.
2003, Downham et al. 2004). In addition, low soil fertility leads to nutrient deficiency and severe attacks by insects and diseases. Chemical fertilisers provide a quick and simple method for enhancing the levels of plant nutrients in the soil. However, in rural areas of Africa, the prices of chemical fertilisers are usually twice the international prices due mainly to transportation costs (Bumb \& Baanante, 1996). Suzuki (IITA HQ, 2013-2015, IITA South Africa hub, 2016-2017) evaluated the efficiency of indigenous rock phosphate (RP) as a natural source of phosphate (Suzuki et al. 2018). While a single new component such as drought or pest resistance may not be effective by itself, specific combinations of the above can work synergistically.

\section{Some like it early: Farmers' preference analysis to improve acceptability of new varieties}

As mentioned above, farmers are not likely to adopt a new cultivar simply because it has improved traits. Typically, small-scale farmers produce several crops in the rainy season, and they spend all their savings to survive the dry season. According to Hayashi (IITA HQ 1994-1995), the farmers plant millet, sorghum, maize, and rice as dietary staples. The farmers also plant legumes such as cowpea, groundnuts, Bambara nuts, soybean; root and tuber crops such as cassava, yam, potato; and okra and tomato. They then sell the surplus of legumes to the local market (Hayashi 2002). Therefore, their cash income is mostly attributable to selling their livestock, and the income from cowpea is limited.

To improve cash income for small-scale farmers in the Sahel region, IITA initiated the strategy to develop a "dual-purpose cowpea" (IITA 1987), and it was advanced in collaboration with the International Livestock Research Institute (ILRI) in the early 1990s (Akundabweni et al. 1990, IITA 1997). During the dry season, high-quality fodder is scarce. Thus, a need was identified to develop dual-purpose varieties that would give reasonable grain and fodder yields, where the above-ground parts of cowpea could be harvested for fodder (sometime pods as well) and thereby suit the diverse needs of farmers in the Sahel region (Adesina et al. 1997, Inaizumi et al. 1999). Inaizumi (IITA HQ 1996-1998) evaluated the diffusion and adoption of IT89KD-288 (a dual-purpose variety) in the northern area of Nigeria. He examined the patterns, levels, and rate of adoption of the dual-purpose cowpea variety, and evaluated the impact of the variety. In this study, $75 \%$ of farmers in Kano state adopted a dual-purpose variety due to its additional fodder yield within four years (Inaizumi et al. 1999). The evaluation revealed that if the variety fulfilled the farmers preferences and performed 
well for them, the adoption could be accelerated further. Farmers are also more sensitive to short-term risks than long-term benefits. Nevertheless, the key component to improve their acceptability of new cowpea cultivars is to grasp their requirements appropriately and to demonstrate conclusive evidence.

Cowpea farmers deal with variable environmental, regional, and socioeconomic conditions and have multiple production objectives that affect their choice of cowpea variety. Farmer participatory varietal selection (FPVS) is a more rapid and cost-effective way to identify farmerpreferred cultivars if a suitable choice of variety exists (Witcomber et al. 1996). Muranaka (IITA Kano station 2003-2010, and HQ 2010-2011) and Ishikawa (IITA Kano station in Nigeria and Saria station in Burkina Faso 2010 2013, and HQ 2013-present) conducted FPVS with more than 3,500 cowpea farmers in Niger and Burkina Faso to understand regional farmers' preferences (Muranaka et al. 2012, Ishikawa et al. 2019a, Ishikawa et al. 2019b). From these results, the grain yield was consistently found to be the most important and common selection criterion for farmers in southeastern Niger and north-central Burkina Faso (Ishikawa et al. 2019a). Interestingly, on the several key criteria nominated by farmers in addition to grain yield, differences in preferences were observed between countries as well as among villages. Farmers in northcentral Burkina Faso generally showed more interest in the criteria related to grain quality as well as early maturation, than those in Niger. Early-maturing cowpea varieties, bearing higher market value compared with latematuring varieties, were mostly preferred by these farmers (Bediako et al. 2009).

These results illustrate that the farmers' selection of cowpea varieties varies, reflecting specific environmental, historical, and cultural factors. Even in the same country, they contribute to significant differences in the selection criteria. Grain yield was the most common and the most important criterion affecting farmers' choice in both regions (Ishikawa et al. 2019b). In order to determine the better acceptance of an improved variety, regional preferences should be gathered and analysed before the release of the variety. However, it is a burden for breeders to conduct FPVS in multiple locations before registration. Ishikawa et al. (2019b) developed the "Selection index" as a simple formula. Using this index, breeders can estimate the acceptability of the new lines before a variety is released.

\section{The great "escape from shame": Social implementation of improved cowpea}

Strong relationships among farmers (especially small-scale farmers), the seed sector, breeders, and other stakeholders in the value chain are essential for the successful dissemination of newly developed and improved crop varieties. Although extensive efforts by various sectors have been made to disseminate the improved varieties of cowpea, they have not reached many countries in West and Central Africa due to weak links or poor communication among stakeholders (Muranaka 2017). In another approach from a rural development perspective, Ishida (IITA HQ 1998-2001) and Wakatsuki (IITA HQ 1986-1988) stated that some projects had been successful in the initial stages using large amounts of energy, resources, and funds, but could not ultimately benefit local farmers in terms of sustainability (Ishida et al. 1998). In addition, their assessments of past projects revealed that most of the capital-based technologies had not lasted beyond the project duration, with the farmers reverting to their indigenous systems (Ishida et al. 1998). Therefore, it is necessary to apply new technologies and varieties that farmers can adapt to their ecological environment and socio-economic conditions. High priority needs to be given to filling these gaps and achieving optimal social implementation.

To overcome these difficulties, Muranaka designed a community-based dissemination scheme, Accelerated dissemination system of improved cowpea varieties via empowered communities in Burkina Faso (AVEC-BF). The central concept of the scheme is the "packaging" of different activities and application to a limited local area. Ishikawa conducted and extended this into a large-scale dissemination scheme (Ishikawa et al. 2015, Ishikawa et al 2017a, Ishikawa 2018). Based on the project, five new varieties were selected by farmers. These varieties were formally registered/released in Burkina Faso in 2013 (IITA press release 2013, IITA the Bulletin 2013a). The extraearly maturing and high-yielding variety, IT99K-573-2-1, was named "Yiisi yande" in the Moore language (a local language of Burkina Faso) meaning "escape from shame" by farmers who participated in FPVS. Fortunately, these results were quickly taken up by the government of Burkina Faso. These varieties were applied to the project of West Africa Agricultural Productivity Program (WAAPP)/Programme de Productivite Agricole en Afrique de l'Ouest (PPAAO) supported by the World Bank, which enhanced social implementation in the country (IITA the Bulletin 2013b). The dissemination rate of improved varieties increased dramatically by up to $72 \%$ around the target regions to reach around 22,934 individual cowpea farmers. In addition, the implementation cost was kept low (Ishikawa et al. 2017a), and all benefits of production were given back to the farmers. These results demonstrate that the rapid dissemination of a new cowpea variety is 
indeed possible when it fulfils the farmers' preferences, farmers can access the seeds of the said variety, and the farmers' skills are sufficient to adopt the new variety.

\section{The bridge on the gaps: Prospects of breeding and research for cowpea}

The necessity of high-throughput evaluation for extensive genetic resources and new breeding materials is becoming increasingly useful. Resources developed from cowpea IT97K-499-35 include a whole-genome shotgun (WGS) assembly, a bacterial artificial chromosome (BAC) physical map, and assembled sequences from 4355 BACs (Muñoz-Amartiain et al. 2017). In particular, the bottleneck in phenotyping and applying remote sensing technologies to crop monitoring and evaluation, which has drawn intense interest over the past decade (Furbank \& Tester 2011), is now successfully addressed by combining novel technologies such as non-invasive imaging, spectroscopy, image analysis, robotics, and highperformance computing. There is a need for continued cowpea breeding activities utilising new technologies to ultimately create high-yielding varieties with resistance to multiple pests.

Ishikawa et al. (2017b) developed a model to calibrate the nitrogen content in a single seed using Fourier transform infrared spectroscopy (FTIR). Using this technique, breeders were able to evaluate the nitrogen content (protein content) of the seed within $20 \mathrm{~s}$ per seed. Moreover, this technique is non-destructive; therefore, it is very useful for the cowpea, in that seed numbers and breeding lines can be saved and breeders can plant the same seed after evaluation. This spectroscopy could also be applied to other physiological analyses. For example, Iseki (IITA HQ, JIRCAS visiting scientist 2016-present) et al. (2020) applied this technique for intra-plant variation analysis. This technique could pave the way for developing other methods to evaluate and enrich the nutritional profile of the cowpea. This would be a much-desired outcome because the cowpea is an incredible source of many health-promoting functional components, minerals, and B-group vitamins (Mudryj et al 2012, Liyanage et al 2014, Jayathilake et al 2018); enhancing not only the yield but also the nutritional value would be highly beneficial.

Although these technical developments and basic research may take time, it will lead to the development of new agri-business opportunities. IITA strongly supports such ventures through its Business Incubation Platform (IITA BIP, IITA annual report 2013, 2016), and IITA youth agripreneurs (IYA, IITA annual report 2013, 2016). For example, Asanuma (IITA HQ, 1979-1983, a board member of IITA from 2018 to present) worked for the isolation and analysis of rhizobia of soybean and cowpea in the 1980s (IITA annual report 1980, 1982, Ayanaba et al. 1983, Asanuma et al. 1985). Based on these studies, the rhizobial inoculation technique underwent much advancement and the rhizobium strain is currently manufactured as "NoduMax" via IITA BIP (IITA annual report 2014). In another revolutionary example, Nakayama (IITA HQ, 1989-1991, food technologist and tofu expert, JICA) developed a procedure for making tofu (Nakayama \& Osho 1996, IITA annual report 1998). As a result, soybean production has increased up to 3.5 million tons in the recent years, and tofu ("awara" or " $k$ 'waidak'wai") is disseminated to West Africa widely, generating a new business opportunity (Nakamura 2011). If the population increase continues and more young people move to urban areas, agricultural production will become stagnant. There is thus an urgent need for agriculture to remain attractive and profitable, with the demonstration of successful examples such as the above.

On the other hand, the most persistent challenge to the expanded production and consumption of cowpea is closing the "yield gap". Although the annual potential yield of the improved cowpea variety is between 2,000 and 3,000 kg/ha (IITA annual report 1974, CSIR 2010), the current global average yield is only $450-650 \mathrm{~kg} / \mathrm{ha}$ (Table 3, Abate et al 2011). To overcome these issues, rapid delivery of the developed varieties and technologies to the end-users (small-scale farmers) is crucial. As mentioned above, IITA has already started several efforts via the Partnerships for delivery (P4D) strategy (IITA annual report 2016, 2017), and has started advocating unification of international collaboration research for development and dissemination. In this regard, IITA leads several mega-initiatives such as Africa Research in Sustainable Intensification for the Next Generation (Africa RISING) program through a grant from USAID as part of the US government's Feed the Future initiative, and African Development Bank Group initiative including the "Africa Feeding Africa" and the Technologies for African Agricultural Transformation (TAAT) programs. These mega-initiatives have a critical strategy for transforming agriculture on the continent with the goal of ensuring that Africa will be able to feed itself through agriculture (IITA special issue 2017). Hereafter, we expect to enhance the cooperative framework between international and national research institutes and dissemination agencies and integrate individual projects and achievements via the One-CGIAR strategy.

\section{Acknowledgements}

I would like to thank Drs. S. Muranaka, J.B. 
Batieno, I. Drabo, O. Boukar, and C. Fatokun, who kindly provided the opportunity to work with IITA cowpea team and INERA Burkina Faso. I also thank Drs. R. Asiedu, C. Fatokun, and O. Boukar who provided a crosscheck of contents and offered critical comments after careful consideration of the manuscript. This work was conducted as part of international collaborative research projects by the Ministry of Agriculture, Forestry and Fisheries of Japan, and the Ministry of Foreign Affairs of Japan. I am grateful to all staff of IITA cowpea breeding program, INERA Saria cowpea team, and all collaborators.

\section{References}

Abaidoo, R. et al. (2017) Evaluation of early maturing cowpea (Vigna unguiculata) germplasm for variation in phosphorus use efficiency and biological nitrogen fixation potential with indigenous rhizobial populations. Journal of Agricultural Science, 155, 102-116.

Abate, T. et al. (2011) Tropical grain legumes in Africa and south Asia -Knowledge and opportunities. Research Report No.1 of the Tropical Grain Legumes II Project. Released December 2011.

Adati, T. et al. (2008) Integrated pest management for cowpeacereal cropping systems in the West African savannah. International Journal of Tropical Insect Science, 27, 123137.

Adati, T. \& Tatsuki, S. (1999) Identification of the female sex pheromone of the legume pod borer, Maruca vitrata and antagonistic effects of geometrical isomers. Journal of Chemical Ecology, 25, 105-115.

Adati, T. et al. (2012) Effect of migration and mating status of the legume pod borer, Maruca vitrata (Fabricius)(Lepidoptera: Crambidae) on the efficacy of synthetic sex pheromone traps in West Africa. In: Innovative research along the cowpea value chain. eds. Boukar, O. Coulibaly, O. Fatokun, C. A. Lopez, K. \& Tamò, M. International Institute of Tropical Agriculture (IITA), Ibadan, Nigeria, 260-272.

Adesina, A. A. et al. (1997) Determinants of farmers' rapid adoption of improved cowpea varieties for dry season cultivation in northern Nigeria. Mimeo, IITA, Ibadan, Nigeria.

Akundabweni, L. S. et al. (1990) Evaluation of elite lines of cowpea (Vigna unguiculata [L.] Walp.) for leaf/fodder plus grain (i.e. dual-purpose). Tropical Agriculture, 67, 133-136.

Alexandratos, N. (1999) World food and agriculture: outlook for the medium and long term. Proceedings of National Academy of Science, USA, 96, 5908-5914.

Asanuma, S. et al. (1985) Use of the enzyme-linked immunosorbent assay (ELISA) in the detection of Rhizobium both in culture and from root nodules of Soja beans and Cowpeas. Canadian Journal of Microbiology, 31, 524-528.

Ayanaba, A. et al. (1983) An agar plate method for rapid screening of Rhizobium for tolerance to acid-aluminium stress. Soil Science Society of America Journal, 47, 256-258.

Badiane, F. A. et al. (2014) Cowpea, In: Broadening the genetic base of grain legumes, eds. Singh, M. Bisht, I. S. \& Dutta, M. Springer, New Delhi. 95-111.

Bediako, J. et al. (2009) Crop storage efficiency and market competitiveness: Case of groundnut and cowpea in Ghana. African Journal of Marketing Management, 1, 81-88.

Boukar, O. et al. (2018) Cowpea (Vigna unguiculata): Genetics, genomics and breeding. Plant Breeding, 138, 1-10.

Bumb, B.L. \& Baanante, C.A. (1996) The role of fertilizer in sustaining food security and protecting the environment to 2020. Food, Agriculture, and the Environment discussion paper. International Food Policy Research Institute, Washington, D.C. 17.

Carsky, H. K. et al. (2001) Contribution of early season cowpea to late season maize in the savanna zone of West Africa. Biological Agriculture and Horticulture, 18, 3030-315.

Cruz, F. J. R. et al. (2014) Growth, nutritional status and nitrogen metabolism in Vigna unguiculata (L.) Walp is affected by aluminum. Australian Journal of Crop Science, 8, 11321139.

CSIR (2010) Annual report, Council for scientific and industrial research, Crops Research Institute, Ghana.

Downham, M. C. A. et al. (2003) Minor components in the sex pheromone of the legume podborer, Maruca vitrata (F.)(Lepidoptera: Pyralidae): development of an attractive blend. Journal of Chemical Ecology, 29, 989-1011.

Downham, M. C. A. et al. (2004) Developing pheromone traps and lures for Maruca vitrata in Benin, West Africa. Entomologia Experimentalis et Applicata, 110, 151-158.

Ehlers, J. D. \& Hall, A. (1997) Cowpea (Vigna unguiculata L. Walp.). Field Crop Research, 53, 187-204.

FAOSTAT (2021) http://www.fao.org/faostat/en, accessed $11^{\text {th }}$ May 2021.

Furbank, R. T. \& Tester, M. (2011) Phenomics-technologies to relieve the phenotyping bottleneck. Trends in Plant Science, 16, 635-644.

Hall, A. E. (2004) Breeding for adaptation to drought and heat in cowpea. European Journal of Agronomy, 21, 447-454.

Hall, A. E. (2012) Phenotyping cowpeas for adaptation to drought, In: Frontiers in research topics. Drought phenotyping in crops: from theory to practice, eds. Monneveux P., Ribaut J. M. \& Okono, A. Frontiers in Physiology, 200-206.

Hayashi, Y. (2002) Village life and indigenous resource management in savanna of West Africa. Asian and African area studies, 2, 70-87. [In Japanese with English summary].

Huynh, BL. et al. (2018) A multi-parent advanced generation inter-cross (MAGIC) population for genetic analysis and improvement of cowpea (Vigna unguiculata (L.) Walp). The Plant Journal, 93, 1129-1142.

IITA (1972) Annual Report 1971, IITA, Ibadan, Nigeria. IITA (1974) Annual Report 1972-73, IITA, Ibadan, Nigeria. IITA (1975) Annual Report 1974, IITA, Ibadan, Nigeria. IITA (1977) Annual Report 1976, IITA, Ibadan, Nigeria. IITA (1979) Annual Report 1978, IITA, Ibadan, Nigeria. IITA (1981) Annual Report 1980, IITA, Ibadan, Nigeria. IITA (1982) Annual Report 1981, IITA, Ibadan, Nigeria. IITA (1983) Annual Report 1982, IITA, Ibadan, Nigeria. IITA (1987) Annual Report and Research Highlights 1986, IITA, Ibadan, Nigeria.

IITA (1995) Annual Report 1994, IITA, Ibadan, Nigeria. IITA (1997) Annual Report 1996, IITA, Ibadan, Nigeria. IITA (1999) Annual Report 1998, IITA, Ibadan, Nigeria. IITA (2014) Annual Report 2013, IITA, Ibadan, Nigeria. IITA (2015) Annual Report 2014, IITA, Ibadan, Nigeria. IITA (2017a) Annual Report 2016, IITA, Ibadan, Nigeria. 
IITA (2017b) IITA: 50 years after. transforming Africa's agriculture and nourishing rural development, IITA, Ibadan, Nigeria.

IITA (2018) Annual Report 2017 - 50 years of research and development: serving the African farmers and communities, IITA, Ibadan, Nigeria.

IITA press release (2013) International Institute of Tropical Agriculture (IITA), Ibadan, Nigeria. http://www.iita. org/2013-press-releases/-/asset_publisher/CxA7/content/ farmers-in-burkina-faso-get-iita-improved-cowpeavarieties?redirect $=\% 2$ F2013-press-releases\#.UQJ1S6VgL_d

IITA the Bulletin (2013a) International Institute of Tropical Agriculture (IITA), Ibadan, Nigeria. No.2155.

IITA the Bulletin (2013b) International Institute of Tropical Agriculture (IITA), Ibadan, Nigeria. No.2200.

Inaizumi, H. et al. (1999) Adoption and impact of dry-season dual-purpose cowpea in the semiarid zone of Nigeria. In: Impact. International Institute of Tropical Agriculture, Ibadan, Nigeria. 14-27.

Iseki, K. et al. (2020) Intra-plant variation in seed weight and seed protein content of cowpea. Plant Production Science, 23, 103-113.

Ishida, F. et al. (1998) Indigenous rice-based lowland farming systems of Nupe, Nigeria. Japanese Journal of Tropical Agriculture, 42, 18-28.

Ishikawa, H. et al. (2015) Development of a community-based dissemination scheme for improved cowpea varieties. Proceedings of Tropentag 2015, Berlin, Germany. Conference on international research of food security, natural resource management and rural development. https://www.tropentag. de/2015/abstracts/full/361.pdf

Ishikawa, H. et al. (2017a) Accelerated dissemination scheme of improved cowpea varieties via empowered communities in Burkina Faso "AVEC-BF" implementation manual. eds H. Ishikawa, I. Drabo, B.B. Joseph, O. Boukar, C. Fatokun, S. Muranaka. International Institute of Tropical Agriculture (IITA), Ibadan, Nigeria, 37-51.

Ishikawa, H. et al. (2017b) Development of calibration model to predict nitrogen content in single seeds of cowpea (Vigna unguiculata) using near infrared spectroscopy. Journal of Near Infrared Spectroscopy, 25, 211-214.

Ishikawa, H. (2018) Beyond a droughty summer. In: Proceeding of the 29th annual conference of the Japan Association for Arid Land Studies. [in Japanese].

Ishikawa, H. et al. (2019a) Comparative analysis of farmers' selection criteria for cowpea (Vigna unguiculata) varieties in Niger and Burkina Faso. JARQ, 53, 159-167.

Ishikawa, H. et al. (2019b) Characteristics of famers' selection criteria for cowpea (Vigna unguiculata) varieties differ between north and south regions of Burkina Faso. Experimental Agriculture, 56, 94-103.

Jayathilake, C. et al. (2018) Cowpea: an overview on its nutritional facts and health benefits. Journal of the Science of Food and Agriculture, 98, 4793-4806.

Kamara, A. Y. et al. (2012) Improvements in grain and fodder yield of cowpea (Vigna unguiculata) varieties developed in the Sudan savannas of Nigeria over the past four decades. In: Innovative research along the cowpea value chain. eds. Boukar, O. Coulibaly, O. Fatokun, C. A. Lopez, K. \& Tamò, M. International Institute of Tropical Agriculture (IITA), Ibadan, Nigeria, 179-188.
Latunde Dada, A. O. (1987) Genetic manipulation of the cowpea (Vigna unguiculata Walp.) for enhanced resistance to fungal pathogens and insect pest. Advances in Agronomy, 44, 133154.

Liyanage, R. et al. (2014) Nutritional properties and antioxidant content of commonly consumed cowpea cultivars in Sri Lanka. Journal of Food Legumes-Indian Society of Pulses Research, 27, 215-217.

Mahalakshmi, V. et al. (2007) Cowpea [Vigna unguiculata (L.) Walp.] core collection defined by geographical, agronomical, and botanical descriptors. Plant Genetics Resources, 5, 113119.

Mortimore. M. J. et al. (1997) Cowpea in traditional cropping systems, in: Advances in Cowpea Research, eds. Singh, B. B., Mohan Raj, D. R., Dashiell, K. E. \& Jackai, L. E. N. Co-publication of International Institute of Tropical Agriculture (IITA) and Japan International Research Center for Agricultural Sciences (JIRCAS), Ibadan, 99-113.

Mudryj, A. N. et al. (2012) Pulse consumption in Canadian adults influences nutrient intakes. British Journal of Nutrition, 108, 27-36.

Muñoz-Amartiain, M. et al. (2017) Genome resources for climate-resilient cowpea, an essential crop for food security. The Plant Journal, 89, 1042-1054.

Muranaka, S. (2017) About AVEC-BF. In: Accelerated dissemination scheme of improved cowpea varieties via empowered communities in Burkina Faso "AVEC-BF", implementation manual. Eds. Ishikawa, H., Drabo, I., Joseph, B. B., Boukar, O., Fatokun, C. \& Muranaka, S. International Institute of Tropical Agriculture (IITA), Ibadan, Nigeria, $\mathrm{x}$-xi.

Muranaka, S. et al. (2012) Cowpea improvement via farmer participatory varietal selection activity in the Republic of Niger. In: Innovative research along the cowpea value chain. eds. Boukar, O., Coulibaly, O., Fatokun, C. A., Lopez, K. \& Tamò, M., International Institute of Tropical Agriculture (IITA), Ibadan, Nigeria, 46-55.

Nakamura, H. (2011) Tohu/tofu in West Africa: Different levels of its localization. Bulletin of Living Science, 33, 123-133. [In Japanese]

Nakayama, O. \& Osho, S. (1996) Tofu Recipes: Introducing tofu (soy cheese) into traditional African foods. IITA, Ibadan, Nigeria.

Ortiz, R. (1998) Cowpeas from Nigeria: a silent food revolution. Outlook on Agriculture, 27, 125-128.

Sanginga, N. et al. (2000) Phosphorus use efficiency and nitrogen balance of cowpea breeding lines in a low P soil of the derived savanna zone in West Africa. Plant and Soil, 220, 119-128.

Singh, B. B. et al. (1990) Insect pests of cowpea. In Insect Pests of Tropical Food Legumes. eds. Singh, S. R., van Emden H. F. \& Taylor T. A., Academic press, London, 99-111.

Singh, B. B. et al. (2002) Recent progress in cowpea breeding. In Challenges and opportunities for enhancing sustainable cowpea production. eds. Fatokun, C. A., Tarawali, S. A., Singh, B. B., Kormawa, P. M. \& Tamò, M., International Institute of Tropical Agriculture (IITA), Ibadan, Nigeria, 2040.

Singh, B. B. \& Matsui, T. (2002) Cowpea varieties for drought tolerance. In Challenges and opportunities for enhancing sustainable cowpea production. International Institute of 
Tropical Agriculture (IITA), Ibadan, Nigeria, 287-300.

Singh, B. B. et al. (2003) Improving the production and utilization of cowpea as food and fodder. Field Crops Research, 84, 167-177.

Singh. B. B. (2014) Cowpea, The food legume of the 21st century. Crop Science Society of America, USA, 38-68.

Suzuki, K et al. (2018) Responses of cowpea genotypes to indigenous rock phosphate application. Agronomy Journal, 110, 1960-1973.

Tarawali, S. A. et al. (1997) Cowpea haulms as fodder. In Advances in Cowpea Research. eds. Singh, B. B., Mohan Raj, D. R., Dashiell, K. E. \& Jackai, L. E. N., International Institute of Tropical Agriculture (IITA) and Japan International Research Center for Agricultural Sciences (JIRCAS), 313-325.

Watanabe, I. (1998) Drought tolerance of cowpea (Vigna unguiculata (L.) Walp.) I. Method for the evaluation of drought tolerance. JIRCAS Journal, 6, 21-28.

Watanabe, I. \& Terao, T. (1998) Drought tolerance of cowpea (Vigna unguiculata (L.) Walp.) II. Field trial in the dry season of Sudan savanna and dry matter production of potted plants under water-stress. JIRCAS Journal, 6, 29-37.

Widders, I. E. (2012) Cowpea: A solution to global challenges. In: Innovative research along the cowpea value chain. eds. Boukar, O., Coulibaly, O., Fatokun, C. A., Lopez, K. \& Tamò, M. International Institute of Tropical Agriculture (IITA), Ibadan, Nigeria, xi-xviii.

Witcomber, J. R. et al. (1996) Farmer participatory crop improvement. I. Varietal selection and breeding methods and their impact on biodiversity. Experimental Agriculture, 32, 445-460. 
Table S1. Typical cultivar of drought or heat tolerant / eary maturing cowpeas in IITA collection

\begin{tabular}{|c|c|c|c|}
\hline Accession number/Cultivar name & Feature trait & Remarks & Reference \\
\hline Aloka (TVu174665) & Drought tolerant & White seed (speakle), brown eye & $\begin{array}{l}\text { Singh et al. } 2002 \\
\text { EDITS-Cowpea database }\end{array}$ \\
\hline Dan Ila (TVu17466) & Drought tolerant & White seed, brown eye & $\begin{array}{l}\text { IITA Cowpea database } \\
\text { Singh et al. } 2002\end{array}$ \\
\hline IT00K-1263 (TVu17211) & Drought tolerant & $\begin{array}{l}\text { Brown seed, dark brown eye } \\
\text { Evaluation in Mozambique }\end{array}$ & $\begin{array}{l}\text { IITA Cowpea database } \\
\text { IITA annual report } 2010\end{array}$ \\
\hline IT00K-901-5 (TVu17213) & Drought tolerant & Evaluation in Nigeria & $\begin{array}{l}\text { IITA Cowpea database } \\
\text { IITA annual report } 2010\end{array}$ \\
\hline IT03K-316-1 (TVu17234) & Drought tolerant & Evaluation in Nigeria & $\begin{array}{l}\text { IITA Cowpea database } \\
\text { IITA annual report } 2010\end{array}$ \\
\hline IT03K-378-4 (TVu17186) & Drought tolerant & Evaluation in Nigeria & $\begin{array}{l}\text { IITA Cowpea database } \\
\text { IITA annual report } 2010\end{array}$ \\
\hline IT04K-227-4 (TVU17193) & Drought tolerant & Evaluation in Nigeria & $\begin{array}{l}\text { IITA Cowpea database } \\
\text { IITA annual report } 2010\end{array}$ \\
\hline IT84S-2246 (TVu17816) & Drought tolerant & $\begin{array}{l}\text { Brown seed, dark brown eye } \\
\text { Evaluation in seedling state }\end{array}$ & Watanabe 1998 \\
\hline IT89KD-245 (TVu-16498) & Drought tolerant & High yielding, Striga resistance & Singh et al. 2002 \\
\hline IT89KD-288 (TVu-16722) & Drought tolerant & & Singh et al. 2002 \\
\hline IT89KD-349 (TVu-17811) & Drought tolerant & & Singh et al. 2002 \\
\hline IT90K-59-2 & Drought tolerant & & Singh et al. 2002 \\
\hline IT97K-1069-6 (TVu-17310) & Drought tolerant & Evaluation in Mozambique & $\begin{array}{l}\text { IITA Cowpea database } \\
\text { IITA annual report } 2010\end{array}$ \\
\hline IT97K-1075-7 & Drought tolerant & & IITA annual report 2001 \\
\hline IT97K-390-2 (TVu-17315) & Drought tolerant & Evaluation in Mozambique & $\begin{array}{l}\text { IITA Cowpea database } \\
\text { IITA annual report } 2010\end{array}$ \\
\hline IT97K-499-35 (TVu-17317) & Drought tolerant & Evaluation in Mozambique & $\begin{array}{l}\text { IITA Cowpea database } \\
\text { IITA annual report } 2010\end{array}$ \\
\hline IT97K-499-39 & Drought tolerant & & IITA annual report 2001 \\
\hline IT97K-568-18 (TVu-17802) & Drought tolerant & Evaluation in Nigeria & $\begin{array}{l}\text { IITA Cowpea database } \\
\text { IITA annual report } 2010\end{array}$ \\
\hline IT97K-634 & Drought tolerant & & IITA annual report 2001 \\
\hline IT97K-819-118 (TVu-17318) & Drought tolerant & & $\begin{array}{l}\text { IITA Cowpea database } \\
\text { IITA annual report } 2010\end{array}$ \\
\hline IT97K-819-154 & Drought tolerant & & Singh et al. 2002 \\
\hline IT98D-1399 (TVu-17453) & Drought tolerant & Evaluation in Nigeria & $\begin{array}{l}\text { IITA Cowpea database } \\
\text { IITA annual report } 2010\end{array}$ \\
\hline IT98K-128-3 (TVu-17455) & Drought tolerant & Evaluation in Mozambique & $\begin{array}{l}\text { IITA Cowpea database } \\
\text { IITA annual report } 2010\end{array}$ \\
\hline IT98K-131-2 (TVu-17456) & Drought tolerant & Evaluation in Nigeria & $\begin{array}{l}\text { IITA Cowpea database } \\
\text { IITA annual report } 2010\end{array}$ \\
\hline IT98K-412-13 & Drought tolerant & Evaluation in Nigeria & IITA annual report 2010 \\
\hline IT98K-452-1 & Drought tolerant & & Singh et al. 2002 \\
\hline IT98K-491-4 (TVu-17797) & Drought tolerant & Evaluation in Nigeria & $\begin{array}{l}\text { IITA Cowpea database } \\
\text { IITA annual report } 2010\end{array}$ \\
\hline IT98K-506-1 (TVu-17326) & Drought tolerant & Evaluation in Nigeria & $\begin{array}{l}\text { IITA Cowpea database } \\
\text { IITA annual report } 2010\end{array}$ \\
\hline IT99K-377-1 (TVu-17339) & Drought tolerant & Evaluation in Nigeria & $\begin{array}{l}\text { IITA Cowpea database } \\
\text { IITA annual report } 2010\end{array}$ \\
\hline IT98K-573-1-1 (TVu-17328) & Drought tolerant & $\begin{array}{l}\text { White seed, back eye, Striga resistance } \\
\text { Evaluation in Nigeria }\end{array}$ & $\begin{array}{l}\text { IITA Cowpea database } \\
\text { IITA annual report } 2010\end{array}$ \\
\hline IT99K-7-21-2-2 (TVu-17348) & Drought tolerant & Evaluation in Nigeria & $\begin{array}{l}\text { IITA Cowpea database } \\
\text { IITA annual report } 2010\end{array}$ \\
\hline Kanannado (TVu803) & Drought tolerant & & Singh et al. 2002 \\
\hline
\end{tabular}

(Continued on next page) 
Evaluation of genetic resources of cowpea and variety development/social implementation

Table S1. Typical cultivar of drought or heat tolerant / eary maturing cowpeas in IITA collection (Continued)

\begin{tabular}{|c|c|c|c|}
\hline Accession number/Cultivar name & Feature trait & Remarks & Reference \\
\hline Suvita 2 (Golom local, TVu15553) & Drought tolerant & $\begin{array}{l}\text { Cream seed, dark brown eye } \\
\text { Evaluation in seedling state }\end{array}$ & $\begin{array}{l}\text { Watanabe } 1998 \\
\text { IITA Cowpea database }\end{array}$ \\
\hline Tvu-11979 & Drought tolerant & Evaluation in seedling state & Watanabe \& Terao 1998 \\
\hline Tvu-11982 & Drought tolerant & $\begin{array}{l}\text { Brown seed, dark brown eye } \\
\text { Evaluation in seedling state }\end{array}$ & Watanabe 1998 \\
\hline Tvu-11986 & Drought tolerant & Evaluation in seedling state & Watanabe \& Terao 1998 \\
\hline Tvu-12348 & Drought tolerant & Evaluation in seedling state & Watanabe \& Terao 1998 \\
\hline Tvu-12349 & Drought tolerant & & Singh et al. 2002 \\
\hline Tvu-124914 & Drought tolerant & Evaluation in seedling state & Watanabe 1998 \\
\hline Tvu-13464 & Drought tolerant & & Singh et al. 2002 \\
\hline Tvu-1362 & Drought tolerant & Evaluation in seedling state & Watanabe 1998 \\
\hline Tvu-1469 & Drought tolerant & Evaluation in seedling state & Watanabe 1998 \\
\hline Tvu-14910 & Drought tolerant & Evaluation in seedling state & Watanabe 1998 \\
\hline Tvu-14915 & Drought tolerant & Evaluation in seedling state & Watanabe 1998 \\
\hline Tvu-2365 & Drought tolerant & Evaluation in seedling state & Watanabe 1998 \\
\hline Tvu-3752 (WEEDY) & Drought tolerant & Evaluation in seedling state & Watanabe 1998 \\
\hline Tvu-433 & Drought tolerant & Evaluation in seedling state & Watanabe 1998 \\
\hline Tvu-4632 & Drought tolerant & $\begin{array}{l}\text { Dark brown seed, black eye } \\
\text { Evaluation in seedling state }\end{array}$ & $\begin{array}{l}\text { Watanabe } 1998 \\
\text { EDITS-Cowpea database }\end{array}$ \\
\hline Tvu-7144 & Drought tolerant & Evaluation in seedling state & Watanabe 1998 \\
\hline Tvu-7841 & Drought tolerant & Evaluation in seedling state & Watanabe 1998 \\
\hline Tvu-8256 & Drought tolerant & Purple mottled seed & $\begin{array}{l}\text { IITA Cowpea database } \\
\text { Singh et al. } 2002\end{array}$ \\
\hline Tvu-8885 & Drought tolerant & Evaluation in seedling state & Watanabe 1998 \\
\hline Tvu-9157 & Drought tolerant & Evaluation in seedling state & Watanabe 1998 \\
\hline Tvu-9178 & Drought tolerant & Evaluation in seedling state & Watanabe 1998 \\
\hline VITA7 (TVx289-4G) & Drought tolerant & Evaluation in Nigeria & IITA annual report 1985 \\
\hline IT88D-643-1 (TVu-17410) & Heat tolerant & & IITA annual report 2001 \\
\hline IT88D-867-11 (TVu-17411) & Heat tolerant & & IITA annual report 2001 \\
\hline IT99K-1058 & Heat tolerant & & IITA annual report 2001 \\
\hline IT99K-1059 & Heat tolerant & & IITA annual report 2001 \\
\hline IT99K-1060 & Heat tolerant & & IITA annual report 2001 \\
\hline Tvu-4552 & Heat tolerant & & IITA annual report 2001 \\
\hline B301 (TVu13950) & Early maturing & Brown seed, Striga resistance & Ishikawa et al. 2019 \\
\hline IT00K-1148 & Early maturing & Brown seed & Ishikawa et al. 2019 \\
\hline IT00K-1150 & Early maturing & & Abaidoo et al. 2017 \\
\hline IT00K-1217 (TVu-17362) & Early maturing & & Abaidoo et al. 2017 \\
\hline IT00K-898-5 & Early maturing & & Abaidoo et al. 2017 \\
\hline IT82D-849 (TVu-15560) & Early maturing & Striga resistance & $\begin{array}{l}\text { IITA Cowpea database } \\
\text { Abaidoo et al. } 2017\end{array}$ \\
\hline IT85D-3428 (TVu-15790) & Early maturing & & Abaidoo et al. 2017 \\
\hline IT85D-3428-4 (TVu-16481) & Early maturing & & Abaidoo et al. 2017 \\
\hline IT85D-3516-2 (TVu-16476) & Early maturing & & Abaidoo et al. 2017 \\
\hline IT85F-1002 (TVu-15763) & Early maturing & & Abaidoo et al. 2017 \\
\hline IT85F-1992 (TVu-15775) & Early maturing & & Abaidoo et al. 2017 \\
\hline IT85F-958 (TVu-16497) & Early maturing & & Abaidoo et al. 2017 \\
\hline IT86D-1008 (TVu-15777) & Early maturing & & Abaidoo et al. 2017 \\
\hline IT86D-1065 (TVu-15770) & Early maturing & & Abaidoo et al. 2017 \\
\hline
\end{tabular}


Table S1. Typical cultivar of drought or heat tolerant / eary maturing cowpeas in IITA collection (Continued)

\begin{tabular}{|c|c|c|c|}
\hline Accession number/Cultivar name & Feature trait & Remarks & Reference \\
\hline IT86D-1073 (TVu-15825) & Early maturing & & Abaidoo et al. 2017 \\
\hline IT86D-345 (TVu-15789) & Early maturing & & Abaidoo et al. 2017 \\
\hline IT89KD-374 (TVu-16502) & Early maturing & & Singh et al. 2002 \\
\hline IT90K-372-1-2 & Early maturing & $\begin{array}{l}\text { White seed, Striga resistance } \\
\text { (evaluation at Burkina Faso) }\end{array}$ & Ishikawa et al. 2019 \\
\hline IT92KD-279-3 & Early maturing & & Abaidoo et al. 2017 \\
\hline IT93K-2045-29 (TVu-17293) & Early maturing & & Abaidoo et al. 2017 \\
\hline IT93K-509-16 (TVu-17302) & Early maturing & & Abaidoo et al. 2017 \\
\hline IT93K-513-2 & Early maturing & IPM good practical performance & $\begin{array}{l}\text { Asante et al. } 2001 \\
\text { Abaidoo et al. } 2017\end{array}$ \\
\hline IT93K-734 & Early maturing & & Abaidoo et al. 2017 \\
\hline IT93KZ-4-5-6-1-5 & Early maturing & & Abaidoo et al. 2017 \\
\hline IT94K-410-2 & Early maturing & & Abaidoo et al. 2017 \\
\hline IT94K-437-1 & Early maturing & & Abaidoo et al. 2017 \\
\hline IT95K-1088-4 & Early maturing & & Abaidoo et al. 2017 \\
\hline IT95K-1384 & Early maturing & & Abaidoo et al. 2017 \\
\hline IT95K-1491 & Early maturing & & Abaidoo et al. 2017 \\
\hline IT95K-181-9 & Early maturing & & Abaidoo et al. 2017 \\
\hline IT95K-207-22 & Early maturing & & Abaidoo et al. 2017 \\
\hline IT95M-190 & Early maturing & & Abaidoo et al. 2017 \\
\hline IT96D-618 & Early maturing & & Abaidoo et al. 2017 \\
\hline IT96D-711 & Early maturing & & $\begin{array}{l}\text { Singh et al. } 2002 \\
\text { Abaidoo et al. } 2017\end{array}$ \\
\hline IT96D-738 & Early maturing & & Abaidoo et al. 2017 \\
\hline IT96D-774 & Early maturing & & Abaidoo et al. 2017 \\
\hline IT97-819-180 & Early maturing & & Singh et al. 2002 \\
\hline IT97K-1042-3 & Early maturing & Multiple virus resistance and tolerance & $\begin{array}{l}\text { Ogunsola et al. } 2010 \\
\text { Abaidoo et al. } 2017\end{array}$ \\
\hline IT97K-1069-6 (TVu-17310) & Early maturing & & Abaidoo et al. 2017 \\
\hline IT97K-1075-7 & Early maturing & & $\begin{array}{l}\text { Singh et al. } 2002 \\
\text { Abaidoo et al. } 2017\end{array}$ \\
\hline IT97K-1101-5 (TVu-17311) & Early maturing & & Abaidoo et al. 2017 \\
\hline IT97K-497-2 (TVu-17446) & Early maturing & & Singh et al. 2002 \\
\hline IT97K-499-35 (TVu-17317) & Early maturing & & Abaidoo et al. 2017 \\
\hline IT97K-499-38 (TVu-17447) & Early maturing & & Abaidoo et al. 2017 \\
\hline IT97K-499-39 & Early maturing & Striga resistance, genotyping & Abaidoo et al. 2017 \\
\hline IT97K-499-8 & Early maturing & & $\begin{array}{l}\text { Singh et al. } 2002 \\
\text { Abaidoo et al. } 2017\end{array}$ \\
\hline IT97K-508-2 & Early maturing & & Singh et al. 2002 \\
\hline IT97K-569-9 & Early maturing & & Abaidoo et al. 2017 \\
\hline IT97K-608-14 & Early maturing & & Singh et al. 2002 \\
\hline IT97K-818-35 & Early maturing & Alectra resistance & Abaidoo et al. 2017 \\
\hline IT97K-819-170 & Early maturing & & $\begin{array}{l}\text { Singh et al. } 2002 \\
\text { Abaidoo et al. } 2017\end{array}$ \\
\hline IT97K-819-180 & Early maturing & & $\begin{array}{l}\text { Singh et al. } 2002 \\
\text { Abaidoo et al. } 2017\end{array}$ \\
\hline IT97K-825-3 (TVu-17319) & Early maturing & & Abaidoo et al. 2017 \\
\hline IT97K-837-8 (TVu-17452) & Early maturing & & Abaidoo et al. 2017 \\
\hline IT98K-1111-1 & Early maturing & & Abaidoo et al. 2017 \\
\hline
\end{tabular}


Evaluation of genetic resources of cowpea and variety development/social implementation

Table S1. Typical cultivar of drought or heat tolerant / eary maturing cowpeas in IITA collection (Continued)

\begin{tabular}{|c|c|c|c|}
\hline Accession number/Cultivar name & Feature trait & Remarks & Reference \\
\hline IT98K-1399 & Early maturing & drought tolerant & Abaidoo et al. 2017 \\
\hline IT98K-166-4 (TVu-17798) & Early maturing & & Abaidoo et al. 2017 \\
\hline IT98K-409-4 (TVu-17325) & Early maturing & White seed, Striga resistance & $\begin{array}{l}\text { IITA Cowpea database } \\
\text { Ishikawa et al. } 2019\end{array}$ \\
\hline IT98K-498-1 & Early maturing & & Abaidoo et al. 2017 \\
\hline IT98K-503-1 (TVu-17326) & Early maturing & White seed, Striga resistance (Niger) & $\begin{array}{l}\text { IITA Cowpea database } \\
\text { Ishikawa et al. } 2019\end{array}$ \\
\hline IT98K-506-1 & Early maturing & White color, black eye & $\begin{array}{l}\text { Abaidoo et al. } 2017 \\
\text { EDITS-Cowpea database }\end{array}$ \\
\hline IT98K-589-2 & Early maturing & & Abaidoo et al. 2017 \\
\hline IT99K-1060 (TVu-17333) & Early maturing & & $\begin{array}{l}\text { IITA Cowpea database } \\
\text { Abaidoo et al. } 2017\end{array}$ \\
\hline IT99K-494-6 & Early maturing & Alectra resistance & Abaidoo et al. 2017 \\
\hline IT99K-529-1 (TVu-17344) & Early maturing & & $\begin{array}{l}\text { IITA Cowpea database } \\
\text { Abaidoo et al. } 2017\end{array}$ \\
\hline TVu-1047 (CLAY K713) & Early maturing & & $\begin{array}{l}\text { IITA Cowpea database } \\
\text { Abaidoo et al. } 2017\end{array}$ \\
\hline TVu-11424 & Early maturing & Dark brown seed & Abaidoo et al. 2017 \\
\hline TVu-12449 & Early maturing & & Abaidoo et al. 2017 \\
\hline TVu-1272 & Early maturing & & Abaidoo et al. 2017 \\
\hline TVu-1332 & Early maturing & & Abaidoo et al. 2017 \\
\hline TVu-1987 & Early maturing & & Abaidoo et al. 2017 \\
\hline TVu-4630 & Early maturing & & Abaidoo et al. 2017 \\
\hline TVu-7676 & Early maturing & & Abaidoo et al. 2017 \\
\hline TVu-8337 & Early maturing & & Abaidoo et al. 2017 \\
\hline TVu-10366 & Early maturing & Light brown seed, brown eye & EDITS-Cowpea data base \\
\hline TVu-1037 & Early maturing & Dark brown seed, black eye & EDITS-Cowpea data base \\
\hline TVu-10466 & Early maturing & Dark brown seed, black eye & EDITS-Cowpea data base \\
\hline $\begin{array}{l}\text { TVu-10513 } \\
\text { (TVX } 5882 \text { - O4E (FROM GLIP)) }\end{array}$ & Early maturing & White seed, back eye & $\begin{array}{l}\text { IITA Cowpea database } \\
\text { EDITS-Cowpea data base }\end{array}$ \\
\hline TVu-12873 & Early maturing & Light brown seed, black eye & EDITS-Cowpea data base \\
\hline TVu-13388 (Kvu 71) & Early maturing & Dark brown seed, black eye & $\begin{array}{l}\text { IITA Cowpea database } \\
\text { EDITS-Cowpea data base }\end{array}$ \\
\hline TVu-14248 & Early maturing & Red seed, black eye & EDITS-Cowpea data base \\
\hline TVu-14253 & Early maturing & Dark brown seed, dark brown eye & EDITS-Cowpea data base \\
\hline TVu-14272 & Early maturing & Brown seed, dark brown eye & EDITS-Cowpea data base \\
\hline TVu-1429 & Early maturing & Black seed, dark brown eye & EDITS-Cowpea data base \\
\hline TVu-14759 & Early maturing & Light brown seed, dark brown eye & EDITS-Cowpea data base \\
\hline TVu-14890 & Early maturing & Light brown seed, dark brown eye & EDITS-Cowpea data base \\
\hline TVu-15114 & Early maturing & Cream (light brown) seed, black eye & EDITS-Cowpea data base \\
\hline TVu-15500 (KVx-60-K26-2) & Early maturing & White seed, dark brown eye & $\begin{array}{l}\text { IITA Cowpea database } \\
\text { EDITS-Cowpea data base }\end{array}$ \\
\hline TVu-15661 (IT86D-1038) & Early maturing & Light brown seed, brown eye & $\begin{array}{l}\text { IITA Cowpea database } \\
\text { EDITS-Cowpea data base }\end{array}$ \\
\hline TVu-15775 (IT85F-1992) & Early maturing & Crean (white) seed, black eye & $\begin{array}{l}\text { IITA Cowpea database } \\
\text { EDITS-Cowpea data base }\end{array}$ \\
\hline TVu-15995 & Early maturing & Cream (white) seed, dark brown eye & EDITS-Cowpea data base \\
\hline TVu-16403 (DAMADAMI) & Early maturing & Brown seed, dark brown eye & $\begin{array}{l}\text { IITA Cowpea database } \\
\text { EDITS-Cowpea data base }\end{array}$ \\
\hline TVu-16521 (GIN89-30) & Early maturing & Light brown seed, black eye & $\begin{array}{l}\text { IITA Cowpea database } \\
\text { EDITS-Cowpea data base }\end{array}$ \\
\hline
\end{tabular}


Table S1. Typical cultivar of drought or heat tolerant / eary maturing cowpeas in IITA collection (Continued)

\begin{tabular}{|c|c|c|c|}
\hline Accession number/Cultivar name & Feature trait & Remarks & Reference \\
\hline TVu-1656 & Early maturing & Light brown seed, dark brown eye & EDITS-Cowpea data base \\
\hline TVu-1886 (LUBIYA) & Early maturing & Black seed, black eye & $\begin{array}{l}\text { IITA Cowpea database } \\
\text { EDITS-Cowpea data base }\end{array}$ \\
\hline TVu-2168 & Early maturing & Dark brown seed, black eye & EDITS-Cowpea data base \\
\hline TVu-2252 (POLON LEEMA) & Early maturing & Brown seed, black eye & $\begin{array}{l}\text { IITA Cowpea database } \\
\text { EDITS-Cowpea data base }\end{array}$ \\
\hline TVu-2845 & Early maturing & White seed, dark brown eye & EDITS-Cowpea data base \\
\hline TVu-3107 & Early maturing & Cream (white) seed, dark brown eye & EDITS-Cowpea data base \\
\hline TVu-3428 & Early maturing & Dark brown seed, black eye & EDITS-Cowpea data base \\
\hline TVu-3947 & Early maturing & Brown seed, dark brown eye & EDITS-Cowpea data base \\
\hline TVu-43 & Early maturing & Black seed, black eye & EDITS-Cowpea data base \\
\hline TVu-4316 & Early maturing & Black seed, black eye & EDITS-Cowpea data base \\
\hline TVu-441 & Early maturing & Dark brown seed, black eye & EDITS-Cowpea data base \\
\hline TVu-4535 (IF H144-1) & Early maturing & Brown seed, dark brown eye & $\begin{array}{l}\text { IITA Cowpea database } \\
\text { EDITS-Cowpea data base }\end{array}$ \\
\hline TVu-6641 (GUINEA PEA) & Early maturing & Light brown seed, dark brown eye & $\begin{array}{l}\text { IITA Cowpea database } \\
\text { EDITS-Cowpea data base }\end{array}$ \\
\hline TVu-6744 & Early maturing & Dark brown seed, dark brown eye & EDITS-Cowpea data base \\
\hline TVu-7719 & Early maturing & Light brown seed, black eye & EDITS-Cowpea data base \\
\hline TVu-7778 & Early maturing & Brown seed, dark brown eye & EDITS-Cowpea data base \\
\hline TVu-7971 & Early maturing & Dark brown seed, black eye & EDITS-Cowpea data base \\
\hline TVu-8 (C 1) & Early maturing & Cream seed, dark brown eye & $\begin{array}{l}\text { IITA Cowpea database } \\
\text { EDITS-Cowpea data base }\end{array}$ \\
\hline TVu-849 (FORTY DAYS) & Early maturing & Dark brown seed, black eye & $\begin{array}{l}\text { IITA Cowpea database } \\
\text { EDITS-Cowpea data base }\end{array}$ \\
\hline TVu-8671 & Early maturing & Dark brown seed, dark brown eye & EDITS-Cowpea data base \\
\hline TVu-8775 (POLON ME) & Early maturing & White color, black eye & $\begin{array}{l}\text { IITA Cowpea database } \\
\text { EDITS-Cowpea data base }\end{array}$ \\
\hline TVu-8877 (KLOUEKANME NO.4) & Early maturing & Black seed, black eye & EDITS-Cowpea data base \\
\hline TVu-9259 & Early maturing & White seed, brown eye & EDITS-Cowpea data base \\
\hline TVu-9357 & Early maturing & Red seed, black eye & EDITS-Cowpea data base \\
\hline TVu-9391 (LAKHPET NO.1) & Early maturing & White seed, brown eye & $\begin{array}{l}\text { IITA Cowpea database } \\
\text { EDITS-Cowpea data base }\end{array}$ \\
\hline $\begin{array}{l}\text { TVu-9474 (MANSURA RED EYE } \\
\text { 11) }\end{array}$ & Early maturing & Cream seed, black eye & $\begin{array}{l}\text { IITA Cowpea database } \\
\text { EDITS-Cowpea data base }\end{array}$ \\
\hline TVu-9848 (NYEZANI NO.2) & Early maturing & Light brown seed, dark brown eye & $\begin{array}{l}\text { IITA Cowpea database } \\
\text { EDITS-Cowpea data base }\end{array}$ \\
\hline TVu-9866 (LUNZU NO.1) & Early maturing & Dark brown seed, dark brown eye & $\begin{array}{l}\text { IITA Cowpea database } \\
\text { EDITS-Cowpea data base }\end{array}$ \\
\hline TVx 1999-02E & Early maturing & & Abaidoo et al. 2017 \\
\hline TVx 2724-01F (TVu-13067) & Early maturing & & Abaidoo et al. 2017 \\
\hline TVx 3380-042E & Early maturing & & Abaidoo et al. 2017 \\
\hline IT00K-1217 (TVu-17362) & Extra-early maturing & White seed, Striga resistance (Niger) & $\begin{array}{l}\text { IITA Cowpea database } \\
\text { Ishikawa et al. } 2019\end{array}$ \\
\hline IT00K-901-5 (TVu-17213) & Extra-early maturing & White seed & $\begin{array}{l}\text { IITA Cowpea database } \\
\text { Ishikawa et al. } 2019\end{array}$ \\
\hline IT82D-752 (TVu-17260) & Extra-early maturing & Tan seed color & $\begin{array}{l}\text { IITA Cowpea database } \\
\text { Singh } 2014\end{array}$ \\
\hline IT82D-889 (TVu-17263) & Extra-early maturing & Red seed color & $\begin{array}{l}\text { IITA Cowpea database } \\
\text { Singh } 2014\end{array}$ \\
\hline IT82D789 (TVu-13680) & Extra-early maturing & Light brown seed color & $\begin{array}{l}\text { IITA Cowpea database } \\
\text { Singh } 2014\end{array}$ \\
\hline
\end{tabular}


Evaluation of genetic resources of cowpea and variety development/social implementation

Table S1. Typical cultivar of drought or heat tolerant / eary maturing cowpeas in IITA collection (Continued)

\begin{tabular}{|c|c|c|c|}
\hline Accession number/Cultivar name & Feature trait & Remarks & Reference \\
\hline IT82E-16 (TVu-13674) & Extra-early maturing & Red seed color & $\begin{array}{l}\text { IITA Cowpea database } \\
\text { Singh } 2014\end{array}$ \\
\hline IT82E-18 (TVu-13675) & Extra-early maturing & Tan seed color & $\begin{array}{l}\text { IITA Cowpea database } \\
\text { Singh } 2014\end{array}$ \\
\hline IT82E-32 (TVu-13676) & Extra-early maturing & Red seed color & $\begin{array}{l}\text { IITA Cowpea database } \\
\text { Singh } 2014\end{array}$ \\
\hline IT82E-60 (TVu-13678) & Extra-early maturing & White color, black eye & $\begin{array}{l}\text { IITA Cowpea database } \\
\text { Singh } 2014\end{array}$ \\
\hline IT82E-9 & Extra-early maturing & Black color & Singh 2014 \\
\hline IT83S-818 (TVu-14185) & Extra-early maturing & White color, black eye & $\begin{array}{l}\text { IITA Cowpea database } \\
\text { Singh } 2014\end{array}$ \\
\hline IT93K-452-1 (SAMPEA8) & Extra-early maturing & $\begin{array}{l}\text { White seed, black eye } \\
\text { IPM good practical performance }\end{array}$ & $\begin{array}{l}\text { Ishikawa et al } 2019 \\
\text { Asante et al. } 2001\end{array}$ \\
\hline IT95K-627-34 & Extra-early maturing & & Singh et al. 2002 \\
\hline IT97K-1042-3 (TVu-17444) & Extra-early maturing & Red seed color & $\begin{array}{l}\text { IITA Cowpea database } \\
\text { Singh } 2014\end{array}$ \\
\hline IT98K-1111-1 (TVu-17321) & Extra-early maturing & White color, black eye & $\begin{array}{l}\text { IITA Cowpea database } \\
\text { Singh } 2014\end{array}$ \\
\hline IT98K-205-8 & Extra-early maturing & $\begin{array}{l}\text { White seed, black eye, } \\
\text { Striga resistance }\end{array}$ & $\begin{array}{l}\text { IITA Cowpea database } \\
\text { Ishikawa et al. } 2019\end{array}$ \\
\hline IT98K-463-7 & Extra-early maturing & & Singh et al. 2002 \\
\hline IT99K-573-2-1 & Extra-early maturing & $\begin{array}{l}\text { White seed, black eye, high yielding, } \\
\text { Striga resistance }\end{array}$ & $\begin{array}{l}\text { IITA Cowpea database } \\
\text { Ishikawa et al. } 2019\end{array}$ \\
\hline TVu-12968 (APC 890) & Extra-early maturing & Cream seed, black eye & $\begin{array}{l}\text { IITA Cowpea database } \\
\text { EDITS-Cowpea data base }\end{array}$ \\
\hline TVu-13939 & Extra-early maturing & Cream (white) seed, dark brown eye & EDITS-Cowpea data base \\
\hline TVu-15687 (IT86D-719) & Extra-early maturing & Cream seed, dark brown eye & $\begin{array}{l}\text { IITA Cowpea database } \\
\text { EDITS-Cowpea data base }\end{array}$ \\
\hline TVu-1609 (PS87Z-26) & Extra-early maturing & Brown seed, brown eye & $\begin{array}{l}\text { IITA Cowpea database } \\
\text { EDITS-Cowpea data base }\end{array}$ \\
\hline TVu-16504 (IT90K-77) & Extra-early maturing & Brown seed, dark brown eye & $\begin{array}{l}\text { IITA Cowpea database } \\
\text { EDITS-Cowpea data base }\end{array}$ \\
\hline TVu-2723 & Extra-early maturing & Cream seed, black eye & EDITS-Cowpea data base \\
\hline TVu-2968 & Extra-early maturing & Brown seed, black eye & EDITS-Cowpea data base \\
\hline TVu-7755 & Extra-early maturing & Brown seed, brown eye & EDITS-Cowpea data base \\
\hline
\end{tabular}

Additional references:

IITA Annual report 2001, International Institute of Tropical Agriculture. IITA,

IITA Annual report 2010, International Institute of Tropical Agriculture. IITA,

IITA cowpea database: http://my.iita.org/accession2

EDITS-Cowpea database: https://www.jircas.go.jp/en/database/edits-cowpea/introduction\#04

Asante, S.K. et al. (2001) Integrated management of cowpea insect pests using elite cultivars, date of planting and minimum insecticide application. African Journals Online, 9 (4), 655-665.

Ogunsola, K.E. et al. (2010) Characterizing genetics of resistance to multiple virus infections in cowpea (Vigna unguiculata L. Walp.) Abrsracts: fifth world cowpea conference: Improving livelihood in the cowpea value chain through advancement of science, September27, Saly, Senegal. 26-27. 
Table S2. Typical resistant cowpea varieties for the key insect pests and diseases in the West Africa savannah

\begin{tabular}{|c|c|c|}
\hline Resistant variety & Remarks & Reference \\
\hline \multicolumn{3}{|l|}{ Aphids (Aphis croccivora) } \\
\hline $\begin{array}{l}\text { Tvu-36, Tvu-408, Tvu-410, Tvu-2740, Tvu-3417, } \\
\text { Tvu-3509, Tvu-2896 }\end{array}$ & Resistant & Singh et al. (1982), Jackai \& Singh (1988) \\
\hline Tvu-26, Tvu-62, Tvu-801, Tvu-3000 & Resistant & Singh et al. $(1982,1984)$ \\
\hline $\begin{array}{l}\text { IT83S-728-5, IT84S-2246-4, IT85D-3577, } \\
\text { IT87S-1394, KVx-426-1 }\end{array}$ & Resistant & Jackai \& Adalla (1997) \\
\hline Mandya local, P-912, P-1475, Tvu-2740 & Resistant & Jayappa \& Lingappa (1988) \\
\hline Dan 1la, IT98K-131-2, IT98K-1092-1 & Resistant & Babura \& Mustapha (2012) \\
\hline Tvu-308, Tvu-9944, IT84S-2246-4, Tvu-9930 & Resistant & Ofuya $(1993,1997)$, Togola et al. (2017) \\
\hline Tvu-2740, TVNu-1158, IT97K-556-6 & Tolerant & Souleymane et al. (2013) \\
\hline $\begin{array}{l}\text { KVx-145-27-6, KVx-165-14-1, KVx-146-27-4, KVx- } \\
146-1, \mathrm{KV}-295-2-124-99\end{array}$ & Resistant / tolerant & Dabiré et al. (2012) \\
\hline \multicolumn{3}{|l|}{ Leafhopper (Empoasca spp) } \\
\hline $\begin{array}{l}\text { Tvu-59, Tvu-123, VITA-1, VITA-3, Tvu-123, TVu- } \\
662 \text {, TVu-1190 }\end{array}$ & Resistant & Oyewale \& Bamaiyi (2013), Singh et al. (1984) \\
\hline \multicolumn{3}{|l|}{ Thirips (Megalurothirips sjostedti) } \\
\hline Tvu-1509 & Monderately resistant & Singh (1977), Salifu et al. (1988) \\
\hline TVx-3236 & Resistant & Rösingh (1980) \\
\hline IT82D-716, IT84S-2246, IT90K-59, IT90K-76 & Monderately resistant / Resistant & Singh et al. (1997) \\
\hline IT90K-277-2, IT91K-180 & Low damage or larger number of pods & Alabi et al. (2003) \\
\hline ITH98-20, TVu1509 & Lower number of thrips populations & Abudulai et al. (2006) \\
\hline ITH98-47 & Lower yield loss & Abudulai et al. (2006) \\
\hline Tvu-2870, TVx-3236 & Monderately resistant & Singh et al. $(1982,1984)$ \\
\hline IT820-716, Sanzi & Resistant & CTA (1991), Omo-Ikerodah et al. (2008) \\
\hline $\begin{array}{l}\text { KVx-404-8-1, KVx165-14-1, KVx404-3J, KVx- } \\
\text { 404-2J, Moussa local }\end{array}$ & Resistant & Dabiré et al. (2012) \\
\hline \multicolumn{3}{|l|}{ Pod borer (Maruca vitrata) } \\
\hline Tvu-946, Tvu-4557 (VITA-5) & Monderately resistant & Jackai (1981), Singh et al. (1982) \\
\hline TVNu-72, TVNu-73 & Resistant & Jackai \& Oghiakhe (1989) \\
\hline VITA-4, Ife Brown & Resistant to peduncle damage & Singh \& Taylor (1978) \\
\hline Tvu-1, TVx3890010F, VICAM-1/SP & Resistant & Jackai (1982) \\
\hline VITA-1, Kamboinse local & Resistant & Macfoy et al. (1983) \\
\hline $\begin{array}{l}\text { IT82E-32, IT82E-77, IT82E-18, TVx-1843-1C, Tvu- } \\
\text { 72-59-25, ER } 7\end{array}$ & Less susceptible & Marfo (1985) \\
\hline IT93K-452-1 & Lowest incidence of larvae in flower & Yusuf (2005) \\
\hline IT86D-719 & Lowest pod damage & Yusuf (2005) \\
\hline $\begin{array}{l}\text { TVNu-64, TVNu-77, Tvnu-84, TVNu-87, TVNu- } \\
\text { 96, TVNu-100, TVNu-133, TVNu-290, TVNu-405, } \\
\text { TVNu-410, TVNu-412, TVNu-433, TVN-u-459 }\end{array}$ & Resistant / highly resistant & Jackai et al. (1996) \\
\hline \multicolumn{3}{|l|}{ Pod sucking bug (Clavigralla tomentosicollis) } \\
\hline Tvu-1, Tvu-1890, Tvu-3164, Tvu-3198, Tvu-3199 & Monderately resistant & Jackai \& Singh (1988) \\
\hline Tvu-3354, Tvu-3355 & Highly resistant for yield & Olatunde (2000) \\
\hline Tvu-3372 & Monderately resistant & Olatunde (2000) \\
\hline TVNu-151, TVNu-72 & Resistant & Koona et al. (2002) \\
\hline IT86D-716 & Resistant & Dabiré et al. (2012) \\
\hline \multicolumn{3}{|l|}{ Bruchids (Callosobruchus maculatus) } \\
\hline Tvu-2027, Tvu-11952, Tvu-11953 & Monderately resistant & Singh \& Singh (1990), Edde \& Amatobi (2000) \\
\hline Tvu-4200 & Resistant & Jackai \& Singh (1988) \\
\hline IT81D-994 & Monderately resistant & Amusa et al. (2013) \\
\hline
\end{tabular}


Evaluation of genetic resources of cowpea and variety development/social implementation

Table S2. Typical resistant cowpea varieties for the key insect pests and diseases in the West Africa savannah (Continued)

\begin{tabular}{|c|c|c|}
\hline Resistant variety & Remarks & Reference \\
\hline $\begin{array}{l}\text { IT04K-334-2, IT04K-343-1, IT06K-141, } \\
\text { IT99K-216-48-1, IT99K494-6, IT99K-529-2 }\end{array}$ & Resistant & Azeez \& Pitan (2014) \\
\hline $\begin{array}{l}\text { IT81D-985, IT84S-2246, KVx-426-2, KN-1, KVx- } \\
\text { 426-9, KVx-30G-246-2-5K }\end{array}$ & Resistant & Dabiré et al. (2012) \\
\hline
\end{tabular}

Anthracnose, brown blotch, Cercospora leaf spot and

bacterial pustule and blight

IT81D-994, IT82E-16, IT82E-18, IT82D-889, $\quad$ Singh (2014)

IT86D-719, IT90K-59-2, IT90K-277-2,

IT97K-556-4, IT98K-205-8

Septoria leaf spot

IT81D-994, IT90K-82-2, IT97K-556-4, Singh (2014)

IT97K-499-35

\begin{tabular}{lc}
\hline Scab & Singh (2014) \\
\hline TVx-3236, IT84S-2246-4, IT90K-59, IT90K-76 & Singh (2014) \\
\hline False smut & IT84D-666, IT97K-556-4 \\
\hline
\end{tabular}

Cowpea mosaic, cowpea Aphid borne mosaic,

backyey cowpea mosaic, cowpea mottle, cowpea cucumber mosaic

IT83D-889, IT83S-818, IT85F-867-5, IT86D-880, $\quad$ Singh (2014)

IT90K-277-2, IT97K-556-4, IT98K-205-8

\begin{tabular}{ll}
\hline Powdery mildew & Singh (2014) \\
\hline IT97K-556-4
\end{tabular}

Root-knot nematode

IT84S-2246-4, IT89D-288, IT89KD-391, IT90K-59

Singh (2014)

Striga and Alectra (parasite weeds)

IT98K-205-8, IT99K-573-2-1

IT90K-372-1-2, IT99K-494-6, KVx-771-10

Evaluation at Niger, Burkina Faso

Evaluation at Burkina Faso

IT90K-59, IT90K-82-2, IT97K-499-35

IT82D-849, Suvita-2, IT81D-994, IT88D-867-11, IT90K-76, TVu-1271, TVu-1272, TVu-1330, TVu4642, TVu-8337, TVu-9238, TVu-11788, TVu-

12415, TVu-12432, TVu-12470, TVu-13035

TVu-9238, TVu-11788, TVu-12415, TVu-12432, TVu-12470

Striga resistant

Alectra resistant

Muranaka et al. (2010), Ishikawa et al. (2019)

Ishikawa et al. (2019)

Singh (2014)

Singh et al. (1997)

Singh et al. (1997)

\section{Additional references:}

Abudulai, M. et al. (2006) Screening of cowpea for resistance to the flower bud thrips, Megalurothrips sjostedti Trybom (Thysanoptera: Thripidae). Journal of Applied Sciences, 6, 1621-1624.

Alabi, O.Y. et al. (2003) Field evaluation of cowpea cultivars (Vigna unguiculata [L.] Walp.) for resistance to flower bud thrips (Megalurothrips sjostedti Trybom) (Thysanoptera: Thripidae). International Journal of Pest Management, 49, 287-291.

Amusa, D.O. et al. (2013) Evaluation of four cowpea lines for bruchid (Callosobruchus maculatus) tolerance. Journal of Natural Sciences Research, 3, 46-52.

Asante, S.K. et al. (2001) Integrated management of cowpea insect pests using elite cultivars, date of planting and minimum insecticide application. African Journals Online, 9, 655-665.

Azeez, O.M. \& Pitan, O.O.R. (2014) Comparative seed resistance in eighty cowpea accessions to the seed bruchid, Callosobruchus maculatus (Fabricius) (Coleoptera: Bruchidae). Archives of Phytopathology and Plant Protection, 47, 1806-1814.

Babura, S.R. \& Mustapha, Y. (2012) Screening for development of host plant resistance to infestation by aphid (Aphis craccivora Koch) in cowpea (Vigna unguiculata [L] Walp). Bayero Journal Pure Applied Sciences, 5, 44-47.

CTA (1991) Les ennemis des cultures vivrières dans le Sahel. Spore, 36. CTA. Wageningen, The Netherlands.

Dabiré, B.C. et al. (2012) An historical review of progress to control key cowpea biotic constraints in Burkina Faso. In: Innovative research along the cowpea value chain. eds. Boukar, O., Coulibaly, O., Fatokun, C. A., Lopez, K. \& Tamò, M., International Institute of Tropical Agriculture (IITA),

Edde, P.A. \& Amotobi, C.I. (2000) Relative resistance of some cowpea varieties to Callosobruchus maculatus (F.)(Coleoptera: Bruchidae). Journal of Sustainable Agriculture, 17, 67-77.

Jackai, L.E.N. (1981) Relationship between cowpea crop phenology and field infestation by the legume pod-borer, Maruca testulalis. Annals of the Entomological Society of America, 74, 402-408.

Jackai, L.E.N. (1982) A field screening technique for resistance of cowpea (Vigna unguiculata) to the pid-borer Maruca testulalis (Geyer) (Lepidoptera: Pyralidae). Bulletin of Entomological Research, 72, 145-156. 
Jackai, L. E. N. et al. (1985) Recent trends in the control of cowpea (Vigna unguiculata) pests in Africa. In: Cowpea Research, Production and Utilization (Eds S. R. Singh and K. O. Rachie). John Wiley and Sons, Chichester, 233-243.

Jackai, L. E. N. \& Daoust, R. A. (1986) Insect pests of cowpea. Annual Review of Entomology, 31, 95-119.

Jackai, L.E.N. \& Singh, S.R. (1988) Screening techniques for host plant resistance to cowpea insect pests. Tropical Grain Legume Bulletin, 35, 2-18.

Jackai, L.E.N. \& Oghiakhe, S. (1989) Pod wall trichomes and resistance of two wild cowpea, Vigna vaxillata accessions to Maruca testulalis (Geyer) (Lepidoptera: Pyralidae) and Clavigralla tomentosicolis Stal (Demiptera: Coreidae). Bulletin of Entomological Research, 79, 595-605.

Jackai, L.E.N. et al. (1996) Resistance to the legume pod borer, Maruca vitrata Fabricius, and the probable modalities involved in wild Vigna. Crop Protection, 15, 753-761.

Jackai, L.E.N. \& Adalla, C.B. (1997) Pest management practices in cowpea: a review. In: Singh BB, Mohan Raj DR, Dashiell K.E. Jackai LEN (eds) Advanced in cowpea research. Co-publication of IITA and JIRCAS, IITA. Ibadan, Nigeria. 240.

Jayappa, B.G. \& Lingappa, S. (1988) Causes of resistance to Aphis craccivora Koch. In: cowpea germplasm in India. International Journal of Pest management, 34, 59-61.

Koona, P. et al. (2002) Resistance in accessions of cowpea to coreid pod-bug Clavigralla tomentosicollis (Hemiptera: Coreidae). Journal of Economic Entomology, 95, 1281-1288.

MacFoy, G.A. et al. (1983) Studies on the legume pod-borer Maruca testlalis (Geyer)-VI. Cowpea resistance to oviposition and larval feeding. International Journal of Tropical Insect Science, 4, 147-152.

Ofuya, T.I. (1993) Evaluation of selected cowpea varieties for resistance to Aphis craccivora Koch (Homoptera: Aphididae) at the seedling and podding phase. Annuals of Applied Biology, 123, 19-23.

Ofuya, T.I. (1997) Control of the cowpea aphid, Aphis craccivora Koch (Homoptera: Aphididae) in cowpea, Vigna unguiculata (L.) Walp. Integrated Pest Management Reviews, 2, 199-207.

Olatunde, G.O. (2000) Relationship between the levels of infestation of pod sucking bug, Clavigralla tomentosicollis and seed yield of selected cowpea cultivars. Journal of Tropical Forest Resources, 16, 121-125.

Omo-Ikerodah, E.E. et al. (2008) Genetic mapping of quantitative trait (QTLs) with effects on resistance to flower bud thrips (Megalurothrips sjostedti) identified in recombinant inbred lines of cowpea (Vigna unguiculata (L.) Walp.). African Journal of Biotechnology, 7, $263-270$.

Rösingh, C. (1980) Untersuchungen uder die Resistenz der Kuherbse, Vigna unguiculata (L.) Walp., gegen Megalurothrips sjostedti (Trybom) (Thysanoptera: Thripidae). PhD thesis, Universität Homenheim, Stuttgart. 64.

Salifu, A.B. et al. (1988) Mechanism of resistance in cowpea, Vigna unguiculata (L.) Walp. genotype, TVx-3236 to the bean flower thrips, Megalurothrips sjostedti (Trybom)(Thysanoptera: Thripidae). 2. Ovipositional nonpreference. Tropical Pest Management, 34, 180-184.

Singh, S.R. (1977) Cowpea cultivars resistant to insect pests in world germplasm collection. Tropical Grain Legume Bulletin, 9, 3-7.

Singh, B. B. \& Taylor, T. A. (1978) Pests of grain legumes and their control in Nigeria. In Pest of Grain Legumes: Ecology and control. eds. Singh, S. R., van Emden, H. F. \& Taylor, T. A., Academic press, London, 99-111.

Singh, B.B. et al. (1982) Cowpea breeding for disease and insect resistance. In: FAO, 1982, Breeding for durable disease and pest resistance, FAO plant production and protection paper, 55. 139.

Singh, B.B. et al. (1984) Cowpea breeding for disease and insect resistance. Breeding for durable disease and pest resistance, FAO plant production and protection paper, 55. 139

Singh, B.B. \& Singh, S.R. (1990) Breeding for bruchid resistance in cowpea. In: Fujii K, Gatehouse AMR, Johnson CD, Mitchell R, Yoshida T (eds) Bruchids and legumes: economic, ecology and co-evolution. Kluwer Academic Publishers, Dordrecht. 219-228.

Souleymane, A. et al. (2013) Screening for resistance to cowpea aphid (Aphis craccivora Koch) in wild and cultivated cowpea (Vigna unguiculata L. Walp.) accessions. International Journal of Environmental Science and Technology, 2, 611-621.

Togola, A. et al. (2017) Host plant resistance to insect pests of cowpea (Vigna unguiculata L. Walp.): achievements and future prospects. Euphytica, 213(239), 1-16.

Yusuf, S.R. (2005) Infestation and damage by Maruca vitrata Fabricius (Lepidoptera: Pyralidae) on some cowpea lines under different cropping systems in Kano, Nigeria. PhD. thesis, Abubakar Tafawa Balewa University, Bauchi. 55. 